Osoba i doświadczenie mistyczne (3) „Filozofia Chrześcijańska” 15 (2018), s. 129-148

doi: $10.14746 /$ fc. 2018.15 .6

\title{
SERGIUSZ NIZIŃSKI
}

Uniwersytet im. Adama Mickiewicza w Poznaniu

Wydział Teologiczny

\section{Polemika Xaviera Zubiriego z fenomenologiczną koncepcją religii}

Kanony współczesnego filozoficznego myślenia o religii wyznaczają fenomenolodzy, którzy wiążą religię z sacrum ${ }^{1}$. Krytyczny wobec tego nurtu Xavier Zubiri tworzy własną metafizyczną koncepcję religii. Poniższy tekst jest jedynie próbą odtworzenia myśli tego hiszpańskiego filozofa. $\mathrm{Z}$ racji obfitości materiału forma artykułu uniemożliwia szczegółowe ukazanie poglądów, przeciwko którym Zubiri występuje.

Dla autora Estructura dinámica de la realidad kluczowymi pojęciami w rozumieniu religii są terminy związane z władzą, jaką ma rzeczywistość. Są nimi władza rzeczywistości, religacja oraz boskość (deidad). Pojęcia te oddają doświadczanie władzy, jaką ma rzeczywistość zarówno wobec człowieka, jak i kosmosu.

\section{Boskość i przejawy jej dzialania}

W przypadku człowieka moc ta ma związek z ludzką sferą osobową. Zubiri wyróżnia w niej element stały oraz zmienny. Pierwszym z nich jest moja rzeczywistość substantywna (realidad sustantiva), czyli osoba (personeidad, persona). Jest to forma rzeczywistości, która nie tylko jest rzeczywista, ale także jest moja. Jestem zatem nie tylko rzeczywisty jak wszystkie rzeczy, ale dodatkowo jestem „swój”, czyli przysługuje mi cecha posiadania samego sie-

${ }^{1}$ Choćby: M. Eliade, Sacrum, mit, historia, thum. A. Tatarkiewicz, Warszawa 1970, s. 160n; R. Otto, Świętość. Elementy irracjonalne w pojęciu bóstwa i ich stosunek do elementów racjonalnych, thum. B. Kupis, Warszawa 1999. 
bie. To posiadanie samego siebie nie jest jakimś aktem, tylko czymś poprzedzającym każdy akt osoby ${ }^{2}$. Natomiast elementem zmiennym ludzkiej sfery osobowej jest Ja czy też osobowość (Yo, personalidad). Nie jest to osoba, tylko bycie (ser) osoby, czyli jej znajdowanie się pośród rzeczy w świecie. Ja (osobowość) się zmienia ze względu na akty, które spełnia osoba, odnosząc się do rzeczywistości wobec niej zewnętrznej. Według Zubiriego osobowość nie jest zasadniczo konceptem psychologicznym, tylko bytowym (entitativo), gdyż jest figurą bycia, które przyjmuje osoba, sprawując swoje akty. Ja oznacza osobę jako ponownie obecną (reactualizada) w aktach tejże osoby. Ja to te akty osoby, które są „późniejsze” niż samoposiadanie. To w nich osoba się reafirmuje i przez to konstytuuje swoje bycie ${ }^{3}$. Modulując swoje bycie, człowiek konfiguruje swoje Ja, realizując się w różnych formach rzeczywistości, gdyż każdy akt osoby jest przyjmowaniem jakiejś formy rzeczywistości. Każde odniesienie do rzeczy, innych osób, do siebie samego, to nowy akt osoby i nowa forma bycia - przejaw życia osobowego. Dlatego, zdaniem Zubiriego, człowiek potrzebuje rzeczywistości względem siebie zewnętrznej, aby mógł się spełniać osobowo ${ }^{4}$.

Zubiri mówi, że człowiek żyje i tworzy swoją osobowość w oparciu o rzeczywistość czy też dzięki niej (desde la realidad). Oparciem dla człowieka nie są rzeczy z racji bycia takimi, jakie są, ale z tej racji, że są rzeczywiste. To rzeczywistość tworzy Ja, choć dokonuje się to dzięki aktom osoby ${ }^{5}$.

Zubiri analizuje szczegółowo, jaka jest rola rzeczywistości w tworzeniu Ja. Jest ona dla Ja czymś ostatecznym, gdyż człowiek dąży do pełnego samoposiadania, a to dokonuje się przez odniesienie do całej rzeczywistości. W tym sensie dla Ja rzeczywistość jest czymś ostatecznym, gdyż do niej odnoszą się finalnie wszystkie ludzkie akty ${ }^{6}$. Ponadto w procesie tworzenia Ja rzeczywistość umożliwia poszczególne ludzkie wybory i do nich niejako przymusza, czyli narzuca się, popychając człowieka do tworzenia się w swojej sferze osobowej ${ }^{7}$. To dzięki tym trzem działającym jednocześnie cechom rzeczywistości wpływa ona na kształt Ja. Tę jej zdolność oddziaływania na osobę Zubiri nazywa władzą boskości ${ }^{8}$ (el poder de la deidad), którą także określa jako władzę rzeczywistości (el poder de lo real) ${ }^{9}$.

2 X. Zubiri, El hombre y Dios, Madrid 2012, s. 58-59 (dalej: HD).

${ }^{3}$ X. Zubiri, El problema filosófico de la historia de las religiones, Madrid 2006, s. 33-34 (dalej: PFHR).

${ }^{4}$ HD, s. 7; A. Pintor-Ramos, Religación y "prueba" de Dios en Zubiri, "Razón y Fe", nov. 1988, s. 324-325.

${ }^{5}$ Por. HD, s. 180.

${ }^{6}$ M. Jagłowski, Realizm transcendentalny Xaviera Zubiriego, Olsztyn 2000, s. 219.

7 PFHR, s. 38-40.

${ }^{8}$ Boskość (deidad) to nie bóstwo czy też Bóg (divinidad).

9 PFHR, s. 61. 
Z kolei zależność Ja od rzeczywistości Zubiri nazywa religacja (religación). Człowiek jako osoba jest rzeczywistością religowaną, to znaczy, że „każdy ludzki akt jest aktualizacją tego, co w rzeczywistości ostateczne, a więc i fundujące tę rzeczywistość"10. Ponieważ w religacji ma miejsce fundowanie ludzkiego Ja, zatem bycie wśród rzeczy nie jest zwykłym przebywaniem w świecie, tylko warunkiem życia osobowego. Zdaniem Zubiriego, religacja nie jest jakimś teoretycznym konceptem, tylko faktem doskonale stwierdzalnym $^{11}$. Innymi słowy, religacja umożliwia życie osobowe ${ }^{12}$. Każdy akt osobowy, choćby najmniejszy, zawsze kształtuje formę mojego bycia osobowego i jest doświadczeniem (experiencia) boskości. Prawdę powiedziawszy, człowiek nie ma doświadczenia boskości - właściwiej byłoby powiedzieć, że człowiek w swoim życiu osobowym jest doświadczeniem boskości ${ }^{13}$.

Trzeba pamiętać, że nie jest to jeszcze doświadczenie Boga/bóstwa (divinidad), jest to doświadczenie rzeczywistości w jej mocy, które nie jest jeszcze żadną religią pozytywną, ale ma związek z religijnością jako taką, bo właśnie to ono leży u podstaw każdej religii. W tym sensie religijność należy do struktury osobowej każdego człowieka. Tak samo religacja nie jest żadną religią pozytywną, ale czymś, bez czego nie istniałaby ona w żadnej formie ${ }^{14}$.

Zubiri stwierdza, że boskość przejawia się nie tylko pod postacią religacji w człowieku, ale także w kosmosie jako władczość (poderosidad) tego, co rzeczywiste ${ }^{15}$. W tym wymiarze boskość to władza żywa, źródło wszystkich rzeczy, władza fundamentu wszystkich rzeczy realnych, kierująca kolektywem ludzkim, władza przeznaczenia, decydująca o jedności fizycznej i moralnej kosmosu, która wszystko wypełnia, która trwa wiecznie. Bóstwa (divinidades) to manifestacje i konceptualizacje boskości ${ }^{16}$. W kulturach prymitywnych boskość jest interpretowana pod postacią animizmu i magii ${ }^{17}$. Z kolei mit religijny to konceptualizacja władzy rzeczywistości jako władczości. W micie rzeczy stają się siedzibą władczości ${ }^{18}$. Z podobną sytuacją mamy do czynienia w starożytnej Grecji. Zubiri uważa, że greckie physis jest odzwierciedleniem boskości. Grecy władzę tę nazywali naturą i sądzili, że jest boska, bo jest we-

${ }^{10}$ M. Jagłowski, Realizm transcendentalny Xaviera Zubiriego, s. 222; A. Pintor-Ramos, Religación..., s. 321.

${ }^{11}$ HD, s. 98-99.

12 PFHR, s. 40; A. Pintor-Ramos, Dios y el problema de la realidad en Zubiri, "Cuadernos de Pensamiento" 1 (1987), s. 112.

13 PFHR, s. 52-53.

14 PFHR, s. 53.

15 Poderosidades - neologizm Zubiriego.

16 PFHR, s. 45-50.

17 D. Gracia, Religación y religión en Zubiri, w: Filosofía de la religión, red. M. Fraijó, Trotta, Madrid 1994, s. 491-512 [s. 7 maszynopis].

18 X. Zubiri, Inteligencia sentiente. Inteligencia y realidad, Madrid 1984, s. 199 (dalej: IRE). 
dług nich nieśmiertelna, niewyczerpywalna, zawsze młoda. Tymczasem, według autora Estructura dinámica de la realidad rzeczy ani nie są bogami, ani nie są boskie, ale mają coś z jednego i drugiego - są właśnie (jedynie) boskością ${ }^{19}$. Uważa on, że boskość jest rzeczywistością rzeczy, o ile te przenoszą władzę Boga oraz manifestują swoje w Nim ukonstytuowanie ${ }^{20}$. Boskość jest obecnością Boga jako rzeczywistości ostatecznej, umożliwiającej wybór i przymuszającej do niego w rzeczach na zasadzie konstytuowania ich rzeczywistości ${ }^{21}$.

\section{Czym jest boskość}

Władza rzeczywistości, czy też władza boskości, jest ufundowana w Bogu. Jest obecna w rzeczach i ma związek $\mathrm{z}$ ich istotą, którą jest Bóg, ale nie jest formalnie władzą Boga. Podobnie rzecz realna nie jest formalnie Bogiem. Niemniej jednak władza rzeczywistości przenosi władzę Boga. Dlatego rzeczy realne są „siedzibą” Boga jako władzy. Władza rzeczywistości (boskości) jest „manifestacją" jej fundamentu, czyli Boga ${ }^{22}$. Zubiri odwołuje się do znanej wypowiedzi św. Teresy z Ávila, która przeżywszy ekstazę w kuchni, stwierdza, że „Bóg jest obecny wśród rondli”. Interpretuje on słowa świętej w ten sposób, że Bóg nie jest dodatkową rzeczą wśród garnków. Według niego przywołane zdanie Teresy oznacza, że dla mistyka boskość jest czymś obecnym w rzeczach ${ }^{23}$. W konsekwencji nie mamy do Boga innego dostępu, jak w rze$\operatorname{czach}^{24}$.

Boskość ukazuje się człowiekowi jako władza transcendentna - nie w takim sensie, jak rozumiemy transcendencja Boga wobec świata, tylko w sensie przekraczania każdej pojedynczej rzeczy, jednocześnie obejmując ich całość ${ }^{25}$. $Z$ boskością jest związany pewien problem - enigma. Nie wiemy bowiem, skąd rzeczy mają tę moc nad człowiekiem, że umożliwiają mu jego życie osobowe. Istnieje pewna tajemnicza dysproporcja między tym, co człowiek przeżywa w religacji, a tym, co rzeczy człowiekowi umożliwiają (życie osobowe i możliwości wyboru) i do czego go obligują (konieczność wybierania) ${ }^{26}$. Tym samym tworzenie Ja nie jest do końca wyjaśnione - Zubiri powiedziałby

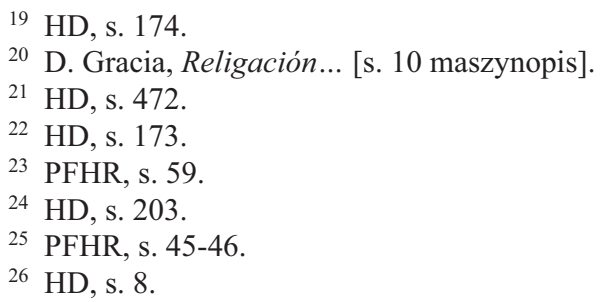


enigmatyczne ${ }^{27}$. Jeśli konfigurowanie Ja ma związek z władzą rzeczywistości (władzą boskości) i religacją, domagają się one fundamentu, który będzie rzeczywistością pełną, uzdalniającą władzę rzeczywistości (boskości) i religację do tworzenia $\mathrm{Ja}^{28}$, dlatego człowiek musi odpowiedzieć sobie na pytanie, co jest fundamentem rzeczywistości. Odpowiedź na nie ułatwia mu znajdowanie się w rzeczywistości i pogodzenie się ze swoją od niej zależnością. Stąd problem fundamentu, a w konsekwencji i Boga, jest problemem mojego życia osobowego ${ }^{29}$.

Ta problematyczność przejawia się jako niepokój obecny w głosie sumienia i w woli prawdy realnej. Prowadzi on do poszukiwania fundamentu. Stawanie się osoby to próby odnalezienia fundamentu mojego Ja. Właśnie w to poszukiwanie wpisuje się $\mathrm{w}$ problem $\mathrm{Boga}^{30}$. Dlatego można powiedzieć, że człowiek staje w swoim wymiarze osobowym, szukając rzeczywistości-fundamentu. Dokonuje się to niezależnie od świadomości, że to właśnie Bóg umożliwia mu życie osobowe. Zubiri tę wewnętrzną ludzką zależność od władzy przenoszonej przez rzeczywistość nazywa odniesieniem te ologalnym. Teologalny (a nie teologiczny - dotyczący Boga) w tym wypadku to dotyczący odniesienia człowieka do Boga obecnego, ale i ukrytego w rzeczach jako ich fundament. Odniesienie teologalne jest wcześniejsze niż jakakolwiek wiara religijna, ale tę wiarę umożliwia ${ }^{31}$. Moment teologalny człowieka jest jego elementem konstytutywnym ${ }^{32}$.

Przybieranie coraz to nowych postaci Ja stanowi stały i konstytutywny niepokój ludzkiego życia ${ }^{33}$. Dlatego głos sumienia nie jest fenomenem czysto moralnym, lecz przede wszystkim metafizycznym. Jest to oddźwięk, echo (resonancia) fundamentu. Głos sumienia nie mówi, czym jest ten fundament, ale jest brzmieniem fundamentu $\mathrm{w}$ ludzkim duchu ${ }^{34}$. Jest on różny u różnych ludzi z odmiennych kultur. Pod wpływem głosu sumienia człowiek wybiera jakąś formę rzeczywistości. Nawiązując do Heideggera, Zubiri pisze o głosie sumienia, który mówi człowiekowi, która forma rzeczywistości jest dlań właściwa ${ }^{35}$. To dyktat władzy boskości poprzedzający każdą religię pozytywną. Dlatego też jest obecny u ateistów lub agnostyków ${ }^{36}$.

27 HD, s. 163.

28 Por. HD, s. 112-114; J. Sáez Cruz, La accesibilidad de Dios: su mundanidad y transcendencia en X. Zubiri, Salamanca 1995, s. 215.

${ }^{29} \mathrm{HD}, \mathrm{s} .122$.

${ }^{30} \mathrm{HD}$, s. $112-114$.

${ }^{31}$ HD, s. 122-123.

32 HD, s. 5-6.

33 PFHR, s. 36.

34 PFHR, s. 64-67.

${ }^{35}$ M. Jagłowski, Realizm transcendentalny Xaviera Zubiriego, s. 230.

36 PFHR, s. 301. 


\section{Wola prawdy realnej}

Poszukiwanie fundamentu wynika $\mathrm{z}$ woli prawdy ${ }^{37}$. Jest ona związana z wolą wybrania jakiejś opcji, którą dostarcza rzeczywistość, uobecniając się w człowieku. Ta obecność rzeczywistości w inteligencji to prawda realna. Rzeczywistość jako prawda niesie w sobie dostępność, stałość i pewność ( $p a-$ tencia, firmeza, efectividad), czyli umożliwia i umacnia życie osobowe. Człowiek pragnie być pełniej, dlatego też ciągle wybiera jakąś formę rzeczywistości. Rzeczywistość-fundament jest prawdą realną w stopniu najwyższym, bo jest źródłem boskości. Wobec tego człowiek, pragnąc umocnić swoje życie osobowe, poszukuje pełni prawdy, którą jest fundament. Ponieważ rzeczy są jedynie wektorami czegoś, co je funduje, co jest pełnią rzeczywistości, szuka on tej pełni, zwracając się ku fundamentowi ${ }^{38}$.

Gdy uzna, że coś może być fundamentem jego Ja, pozwala mu się dziać w sobie, czyniąc go swoim. Wtedy wola prawdy staje się wolą fundowania ${ }^{39}$. Jest ona zasadą początkową ludzkiego życia osobowego rozumianego jako konfigurowanie własnego $\mathrm{Ja}^{40}$. To właśnie ona inicjuje proces opisany poniżej, który ukaże poszczególne kroki szukania fundamentu, prowadzące do powstania religii (w celu umacniania życia osobowego). Wola fundowania nie jest jednorazowym aktem, ale pewnym stanowiskiem/stosunkiem, czyli czymś stałym w ludzkim życiu ${ }^{41}$. Wola prawdy stoi u genezy religii, czyli pewnego doświadczenia Boga umożliwiającego umacnianie życia osobowego ${ }^{42}$.

Zubiri mówi, że obecność źródłowa Boga w osobie ludzkiej przybiera szczególną postać. Ma ona charakter dynamicznego napięcia. Konkretnie jest to napięcie interpersonalne ${ }^{43}$. Bóg jako fundament nie jest czymś zewnętrznie dodanym do człowieka, gdyż go funduje. Dlatego moja relacja do Niego ma charakter życiowy, jest bliskością (intimacion) życiową. Z racji bycia fundamentem Jego obecność jest we mnie dynamiczna. Jest to dynamizm religujący, czyli obecny w konfigurowaniu mojego Ja. Bóg jest fundamentem pełni mojego życia, całego mojego bycia. To wszystko, zdaniem Zubiriego, zaciera różnicę między Bogiem a człowiekiem. Ja jest rzeczywiste, będąc w Bogu. $\mathrm{Z}$ drugiej strony nie jestem Bogiem, tylko sobą. Człowiek i Bóg nie są sobie przeciwstawieni. Bycie nie-Bogiem jest pewnym sposobem bycia człowieka „W” Bogu. Właśnie to stanowi „napięcie teologalne”, które konstytuuje ludz-

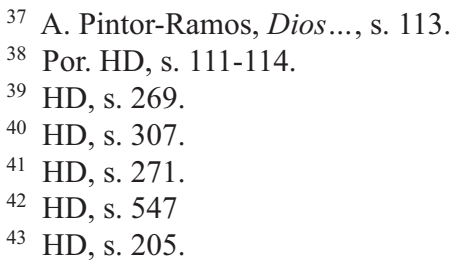


kie życie osobowe ${ }^{44}$. Człowiek jest istotą otwartą, co przejawia się w religacji. Dlatego w swojej relig ow anej otwartości jest rzucony „ku” Bogu. Dostęp do Niego nie ma charakteru spotkania, tylko „odniesienia”, czyli bycia „ku” dzięki rzeczom, które są „w” Bogu, bo Bóg jest ich fundamentem, przyczyną wewnętrzną. Dlatego człowiek musi tworzyć swoje Ja „w” Bogu. Tworzy je „w” Bogu (ostateczność), z Bogiem (możliwość) i dla Boga (pobudzenie). Ta zależność tworzy napięcie teologalne między Bogiem a człowiekiem $^{45}$.

Obecność Boga w rzeczach konstytuuje (constituyente) istotę każdej rzeczy. Bóg jest formą każdej rzeczy. Należy to rozumieć jako konstytuujące rzecz dawanie Boga $z$ siebie samego. Powoduje ono, że rzeczy są realne i działają dzięki temu, czym są z siebie. To też jest powodem nazywania Boga przez Zubiriego rzeczywistością źródłową (realitas fontanalis). To ona powoduje w człowieku napięcie teologalne. Choć rzeczywistość Boga jest niezależna od świata, a więc Bóg jest wobec świata transcendentny, to jednak dostęp do boskiej transcendencji jest przez rzeczy i tylko w nich, bo Bóg jest źródłem realności rzeczy i ich władzy wobec Ja. Dlatego Zubiri mówi, że Bóg jest transcendentny w rzeczach ${ }^{46} \mathrm{i}$ jest On transcendencją źródłową ${ }^{47}$.

Napięcie teologalne pokazuje, że człowiek i Bóg są różni, ale nie są sobie obcy, bo Bóg jest obecny wewnętrznie i formalnie w każdej rzeczy realnej, także w człowieku. Ponadto przez władzę boskości konstytuuje ludzkie Ja. Dlatego relacja donacji Boga w boskości jako rzeczywistości źródłowej i ludzka odpowiedź w postaci przyjęcia tejże donacji ma dla człowieka charakter wewnętrzny, a nie zewnętrzny. Przyczynia się ona do umocnienia życia osobowego. Zubiri mówi, że osoba Boga jest momentem formalnym człowieka tworzącego swoje Ja. Człowiek, tworząc swoje Ja, nie czyni tego całkowicie sam jako osoba zupełnie niezależna od Boga. Każda aktywność człowieka, w tym tworzenie własnego Ja, ma miejsce „w” rzeczywistości i „w” Bogu. Działanie Boga nie jest jakimś dodatkiem do mojego działania. Używając języka antropomorficznego, można powiedzieć, że Bóg skomplikował (ha complicado) swoją boską rzeczywistość, dając się ad extra osobom ludzkim. To bycie nie-Bogiem jest elementem pozytywnym bycia osobą ludzką. Wzajemne zawieranie się czy też pociąganie się Osoby Boskiej i ludzkiej jest napięciem. Napięcie to jest przyczynowaniem osobowym, o czym za chwilę ${ }^{48}$.

44 HD, s. 177-179.

${ }^{45}$ HD, s. 200; J. Sáez Cruz, La accesibilidad..., s. 223.

46 HD, s. 11

${ }^{47}$ HD, s. 194-195; J. Sáez Cruz, La accesibilidad..., s. 183; F. Llenín Iglesias, La realidad divina. El problema de Dios en Xavier Zubiri, Oviedo 1990, s. 112-113.

${ }^{48}$ HD, s. 574. 
Aby oddać charakter zależności czy też więzi między Bogiem a człowiekiem, Zubiri wprowadza termin przyczynowania międzyosobowego. Oddziaływanie między Bogiem a człowiekiem na poziomie osobowym nie ma charakteru przyczynowego $\mathrm{w}$ tym sensie, w jakim rozumie je fizyka. Działanie Boga w napięciu międzyosobowym ma charakter przyczynowania (causal), ale nie jest to ani przyczynowanie sprawcze, ani celowe. Między osobami ma miejsce funkcyjność (funcionalidad). Jest to przyczynowanie między osobami, czyli pomiędzy tym, „kim” są osoby. Jest to przyczynowość osobowa (causalidad personal), którą nie zajmują się nauki przyrodnicze ${ }^{49}$.

Przyczynowość osobowa jest ściśle metafizyczna. Przyjaźń, wsparcie, towarzyszenie nie mają charakteru wyłącznie psychologicznego. Struktura metafizyczna rzeczywistości osobowych jest wcześniejsza od poziomu psychologicznego. Według Zubiriego przyjaźń jest modalnością metafizyczną przyczynowości międzyosobowej i pozwala zrozumieć przyczynowość międzyosobową Boga z każdym człowiekiem. Oznacza ona, że każda forma ludzkiego odniesienia do Boga jest czymś radykalnie wewnętrznym w stosunku do osoby ludzkiej i jest czymś, co stanowi moment dynamizmu wewnętrznego i formalnego, według którego rozwija się życie osobowe. Bóg, będąc we wnętrzu człowieka, pomaga mu właśnie z jego wnętrza. Dlatego pomoc, słuchanie, pocieszanie, jakiego doświadcza się ze strony Boga, mają charakter metafizyczny. Nie są to momenty tylko psychicznego życia ludzkiego, są to momenty pierwotnie metafizyczne. Dlatego, niezależnie od świadomości, człowiek ma doświadczenie Boga. Nie jest to doświadczenie empiryczne jakiegoś przedmiotu, ale doświadczenie metafizyczne fundowania własnego bycia osoby (Ja). Jest to samo w sobie doświadczenie Boga ${ }^{50}$.

\section{Metoda poszukiwań fundamentu. Rozum teologiczny}

Diego Gracia stwierdza, że metodą, którą posługuje się człowiek w poszukiwaniu fundamentu rzeczywistości, jest rozum teologiczny (razón teológica) nastawiony na poszukiwanie bóstwa (divinidad) ${ }^{51}$. Odpowiada on za powstanie religii. W tym miejscu warto zadać pytanie: Jak Zubiri definiuje rozum? Jest on (w bardzo dużym uproszczeniu) jedną z trzech modalności władzy poznawczej, którą Zubiri nazywa inteligencją odczuwającą. Pierwsza modalność tej władzy to aprehensja pierwotna. Dzięki niej rzecz jest jedynie percypowana jako impresja czegoś realnego ${ }^{52}$. W aprehensji pierwotnej nie wiem, czym

\footnotetext{
49 HD, s. 220.

50 HD, s. 220-224.

51 D. Gracia, Religación... [s. 13 maszynopisu].

52 IRE, s. 12-13.
} 
rzecz jest, bo jest to jeszcze faza czysto receptywna i przedjęzykowa ${ }^{53}$. Druga modalność to logos, który odnosi percypowaną rzecz do zasobu idei, jakim człowiek dysponuje w celu porównania rzeczy z nimi i ujęcia, czym jest rzecz $\mathrm{W}$ stosunku do innych rzeczy ${ }^{54}$. Z kolei rozum, bazując na aprehensji pierwotnej oraz logosie, próbuje poznać fundament rzeczy, czyli rzeczywistość głęboką. Aby zobrazować, czym jest rozum, Zubiri posługuje się przykładem poznania, czym jest kolor. Jest on wpierw percypowany jako pewna rzeczywistość (aprehensja pierwotna), następnie jako kolor zielony (logos). Na końcu rozum poznaje jego istotę, stwierdzając, że kolor zielony jest falą elektromagnetyczną lub fotonem. Fala elektromagnetyczna, foton to rzeczywistość fundująca, rzeczywistość w głębi ${ }^{55}$. Innymi słowy, kolor zielony według poznania racjonalnego (czy też rozumu) jest w istocie falą elektromagnetyczną lub fotonem $^{56}$. Rozum jest właśnie dotarciem do prawdy o tym, czym jest barwa w głębi. Jest to zatem rozumne wyjaśnienie, czym rzecz jest. Poszukiwanie fundamentu nie jest jednoznaczne i może być wielokierunkowe ${ }^{57}$. Właśnie $\mathrm{z}$ takim działaniem inteligencji mamy do czynienia w religii, gdzie rozum szuka fundamentu boskości. Ponieważ może on być metafizyczny (szuka on wówczas fundamentu rzeczywistości), poetycki, naukowy (jak w przypadku wyjaśniania, czym jest światło), tak samo może być teologiczny, czyli z góry nastawiony na znalezienie jakiegoś bóstwa (divinidad) we władzy boskości (deidad). W przypadku religii mamy do czynienia z ostatnim typem rozumu ${ }^{58}$.

Wychodzi on od tego, co jest dane, czyli od władzy boskości, i szuka w rzeczach ich fundamentu wyjaśniającego boskość. Chodzi więc o fundament wszystkich aspektów boskości (ostateczność, stwarzanie możliwości wyboru i przymuszanie do wybierania), a więc tego, co umożliwia tworzenie ludzkiego Ja w każdym jego aspekcie ${ }^{59}$.

Jedna z definicji rozumu, jaką podaje Zubiri, brzmi tak: rozum to intelekcja (intelección), w której rzeczywistość głęboka (realidad profunda) obecna jest $\mathrm{w}$ inteligencji problematycznie i rzuca ją do poszukiwania według kanonu tego, co realne $\mathrm{w}$ głębi ${ }^{60}$. Dla nas punktem wyjścia jest problematyczność boskości, która skłania człowieka do szukania jej fundamentu ${ }^{61}$.

Rzeczywistość w głębi, czyli rzeczywistość fundująca, jest tym, co przekracza rzeczy, które doświadczamy (czyli władzę boskości). Znaczy to, że nie

\footnotetext{
53 M. Jagłowski, Realizm transcendentalny Xaviera Zubiriego, s. 82-83.

54 X. Zubiri, Inteligencia y logos, Madrid 2008, s. 55-56 (dalej: IL).

55 X. Zubiri, Inteligencia y razón, Madrid 2008, s. 43 (dalej: IRA).

56 IRA, s. 12.

${ }_{57}$ M. Jagłowski, Realizm transcendentalny Xaviera Zubiriego, s. 93.

58 IRA, s. 151-154.

59 PFHR, s. 294.

60 IRA, s. 65.

${ }^{61}$ IRA, s. 95.
} 
poznajemy fundamentu bezpośrednio, lecz przez to, co jest bezpośrednio dane, czyli przez boskość (i zawarty w niej kierunek ku fundamentowi). Fundament ze swej strony jest tym, co pozwala poznać lepiej to, co bezpośrednio dostępne, czyli władzę rzeczywistości ${ }^{62}$. Nie wiemy, co może być fundamentem boskości, bo ten nie jest dany wprost. Stąd też rozum jest marszem (marcha) w kierunku nieznanego ${ }^{63}$. Jeśli poprzednie dwa etapy intelekcji (aprehensję pierwotną i logos) Zubiri umieszczał na poziomie poznania fenomenologicznego, to rozum jest myśleniem zmierzającym ku temu, co nie jest dane ${ }^{64}$.

Należy podkreślić, że myślenie zaczyna się od tego, co dane. To rzecz „daje do myślenia”, jednocześnie uaktywniając inteligencję do poszukiwań. Wtedy też rozum inteliguje rzecz tak, jak ona daje się pomyśleć. To rzecz daje rozum $^{65}$. Szukanie fundamentu nie dokonuje się w duchu racjonalistycznym. Tutaj Zubiri opowiada się zdecydowanie przeciw racjonalizmowi ${ }^{66}$. To boskość w swojej problematyczności wymusza na nas poszukiwanie fundamentu, które jest zawsze późniejsze wobec doświadczenia rzeczywistości ${ }^{67}$. To rzeczywistość wyrzuca inteligencję w pewnym kierunku ${ }^{68}$.

Gracia mówi, że istnieją cztery etapy rozumu teologicznego, które wyrażają jednocześnie wolę prawdy: system referencji, szkic, doświadczenie oraz weryfikacja $^{69}$. W kolejnych paragrafach zostaną ukazane szczegółowo.

\section{System referencyjny}

Rzeczywistość inteligowana jest miarą (mensura) intelekcji jako rozumu. Każda rzecz jest pewną formą fundamentu, czyli jest przez ten fundament determinowana. To zdeterminowanie to miara. Stąd rzeczywistość to miara, według której każda rzecz jest realna, jest „z siebie”. Miara w każdej rzeczy jest następstwem obecnego $\mathrm{w}$ niej fundamentu ${ }^{70}$. W intelekcji racjonalnej jest inteligowana zas ada-miara tego, co rzeczywiste. Wskutek tego jest miarą samej siebie. Ta zasada-miara to kanon. Nie ma on jednak definitywnego charakteru. Może być konceptualny, emocjonalny, metaforyczny. Zmienia się wraz $\mathrm{z}$ liczbą inteligowanych rzeczy. $Z$ jednej strony zawęża intelekcję rzeczywi-

\footnotetext{
62 IRA, s. 42-43.

63 IRA, s. 20-21.

64 IRA, s. 25.

65 M. Jagłowski, Realizm transcendentalny Xaviera Zubiriego, s. 95-96.

66 IRA, s. 32.

67 IRA, s. 34.

68 M. Jagłowski, Realizm transcendentalny Xaviera Zubiriego, s. 217.

69 D. Gracia, Religación ... [s. 13 maszynopisu].

70 IRA, s. 44.
} 
stości, z drugiej ją umożliwia ${ }^{71}$. Wyznacza jedynie kierunek poszukiwań fundamentu. Każde poszukiwanie ma precyzyjny kierunek zdeterminowany przez to, co dostarczyły aprehensja pierwotna i logos, na których opiera się kanon. Zawsze można go ulepszyć. Stąd prawda rozumu może być przezwyciężona ${ }^{72}$.

Choć poszukiwanie fundamentu (rzeczywistości głębokiej) ma charakter kreatywny i wolny, to wolność ta jest ograniczona. Jest to spowodowane tym, że fundament musi wyjaśniać to, co dane w aprehensji pierwotnej ${ }^{73}$. Percypowane $\mathrm{w}$ niej rzeczy są bowiem rezonatorem fundamentu ${ }^{74}$, który w procesie tym narzuca się człowiekowi w tym sensie, że niejako wymusza na nim odnalezienie tego, co jest tym fundamentem ${ }^{75}$. Przechodząc do omawianej przez nas kwestii, czyli problematyczności tworzenia Ja na podstawie władzy boskości, należy uwzględnić, że charakter jej działania w stosunku do Ja stanowi sugestię, czym fundament może byćc ${ }^{76}$. Sprowadza się to do tego, że „kierunek" odczuty we władzy boskości ma charakter inicjujący działanie rozumu, umożliwiając mu szukanie fundamentu ${ }^{77}$. Nie ma poznania fundamentu bez odniesienia do władzy rzeczywistości, która jest w tym wypadku systemem referencyjnym (punktem odniesienia) dla rozumu ${ }^{78}$.

\section{Szkic}

Do fundamentu możemy dotrzeć tylko, szkicując to, czym on może być. Mówiąc inaczej: potrzebujemy hipotezy (szkicu), aby poznać, czym ten fundament może być. Szkic jest pewną konstrukcją ${ }^{79}$. Szkic fundamentu wymyśla się (se inventa) według kanonu. Ma to na celu przedstawienie racji, dla których to, co dane bezpośrednio, jest takie, jakie jest ${ }^{80}$. To znaczy szkic (hipoteza) ma wyjaśniać zagadkę/enigmatyczność tego, co jest dane bezpośrednio. Zubiri mówi, że intelekcja rozumowa dodaje rzeczywistości pewną nową strukturalnie wykreowaną $\mathrm{w}$ wolny sposób treśćc ${ }^{81} \mathrm{i}$ właśnie ona jest hipotetycznym (bo jeszcze niezweryfikowanym) fundamentem ${ }^{82}$. Tworząc istotę czy też kreśląc

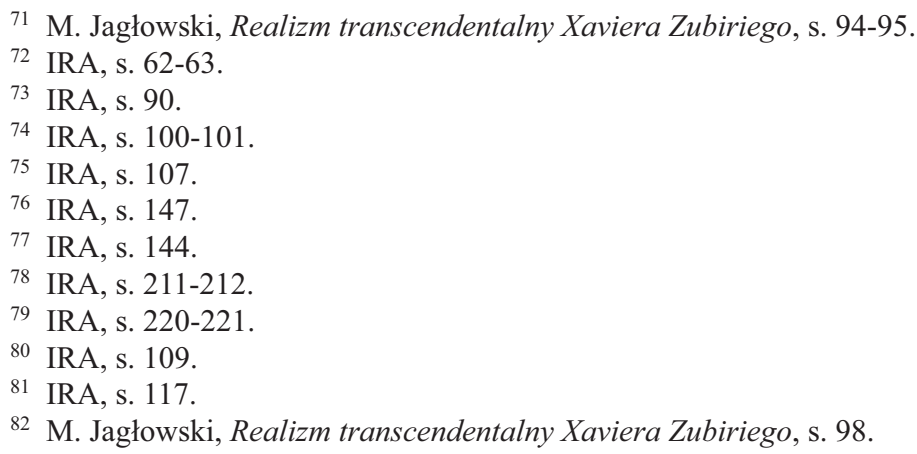


szkic fundamentu, rozum przewiduje, czym rzecz mogłaby być (prodría ser) w swej głębi ${ }^{83}$. Trzeba podkreślić, że we władzy rzeczywistości jest zawarta sugestia, czym mógłby być fundament. Każdy szkic opiera się na tej sugestii ${ }^{84}$.

Rzecz jest dla nas manifestacją (menifestación) jej fundamentu. Zmusza intelekcję do zmierzania w jego kierunku. Można więc powiedzieć, że zawiera w samej sobie pewien szacunek tego, co jest jej fundamentem. Dlatego rozum to marsz szacunkowy (en tanteo) ${ }^{85}$. Boskość zawiera już pewien szacunek tego, co może być jej fundamentem. Można powiedzieć także inaczej: sama postać religacji jest już pewnym szacunkiem tego, jaki powinien być Bóg. Dlatego szkicowanie fundamentu nawiązuje do boskości. To prowadzi do takiego szkicu bóstwa, które jest rzeczywistością ostateczną, dającą możliwości wyboru i nakłaniającą do wyboru. Bez takiego typu szkicu nigdy nie odkryje się fundamentu ${ }^{86}$.

Nie jest oczywiste, że władza rzeczywistości wymaga szkicu typu teistycznego. Historia religii pokazuje, że zarówno idee teistyczne, jak i nieteistyczne są równoważne ${ }^{87}$. Zubiri zauważa, że na podejście rozumu do boskości mają wpływ czynniki indywidualne, społeczne, kulturowe, psychologiczne. Są one często nieświadome ${ }^{88}$ i wpływają na kanon. Zubiri nazywa je forma mentis. Tutaj widać to, kim się jest: na przykład Grekiem lub Semitą ${ }^{89}$. Każdy człowiek szuka Boga z perspektywy swojej społeczności i kultury. Dlatego rozum zawsze jest już jakoś określony z uwagi na poszukiwania (razón instalada), stąd droga poszukiwania Boga już mu się jakoś jawi. Nie stanowi to jednak przeszkody w poszukiwaniu. Największy wpływ na sposób poszukiwania Boga wywierają znaczące jednostki. Są to fundatorzy religii. W tym sensie szukanie Boga przez szacunek, a następnie szkic, jest zawsze doświadczeniem historycznym ${ }^{90}$. Religia bowiem nie jest niczym indywidualnym. Będąc doświadczeniem Absolutu, jest odkryciem kolektywnym. Dlatego Zubiri mówi, że pod tym względem doświadczenie religijne nie jest atrybutem pojedynczego człowieka, tylko konkretnych ludzi. Stąd doświadczenie Żydów było inne niż pozostałych narodów Wschodu ${ }^{91}$. Jeśli wobec władzy rzeczywistości pojawia się jakiś uprzywilejowany szkic, to dlatego, że ku temu rozwiązaniu skłaniają się kultura i język danego społeczeństwa ${ }^{92}$.

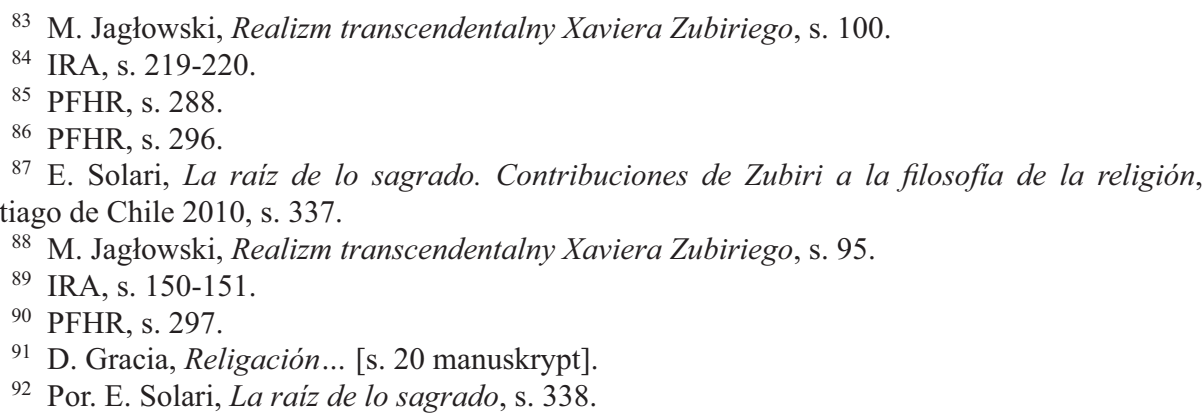




\section{Doświadczenie (experiencia) oraz weryfikacja}

Dalszym krokiem rozumu jest doświadczenie (experiencia), czyli sprawdzenie, czy obrany szkic jest właściwy. Nie jest to konstatacja czysto umysłowa, tylko fizyczna próba ${ }^{93}$. Zubiri uznaje za błąd poszukiwanie Boga jedynie w ramach czystej dialektyki rozumu rozumującego (razón razonante). Właściwe poszukiwanie Boga obejmuje następujące wymiary: moralny, uczuciowy, indywidualny, społeczny, ludzkiego bycia osobowego, w którym Bóg jest doświadczany ${ }^{94}$. Doświadczenie polega na umieszczeniu szkicu w kontekście religacji na zasadzie próby w celu sprawdzenia, czy do niej pasuje ${ }^{95}$. Jeśli początkowo idzie się od faktu konfigurowania Ja w religacji (w którym są zawarte sugestie odnośnie do tego, czym mogłaby być rzeczywistość głęboka), tworząc szkic fundamentu, to teraz w doświadczeniu idzie się na nowo do religacji, sprawdzając, czy szkic w niej umieszczony ją wyjaśnia, to znaczy, czy rozwiązuje enigmę tworzenia ludzkiego Ja dzięki władzy rzeczywistości ${ }^{96}$.

Jeśli fundament nigdy nie jest dany ani w aprehensji pierwotnej, ani w logosie, to ma się do niego dostęp dzięki doświadczeniu ${ }^{97}$. Umożliwia ono weryfikację szkicu fundamentu. Rodzaj weryfikacji zależy od rodzaju rozumu i od rodzaju szkicu. Inaczej się weryfikuje hipotezę naukową w ramach metody ilościowej (eksperymentu), a inaczej szkic Boga w ramach doświadczenia (experiencia).

Spośród różnych form doświadczenia należy wymienić dwa. Pierwszy to wzajemne przenikanie się (compenetración), w którym ten, kto dokonuje tego doświadczenia, umieszcza się w rzeczywistości doświadczanej. Gracia wyjaśnia, że muszą być wówczas obecne dwie osoby. Bóg jest obecny w świecie we władzy rzeczywistości, religacji i boskości. Dzięki szkicowi Jego obecność zostaje ukazana na przykład jako obecność osobowa w świecie. Szkic ten zakłada także, że świat jest donacją osobową Boga, która przejawia się jako prawdziwe przyciąganie (arrastre) człowieka w celu tworzenia Ja. Bóg przyciąga go w rzeczach jako osobowy fundament, a człowiek odpowiada na to przez zawierzenie (entrega). Współprzenikanie to przyciąganie ze strony Boga i zawierzenie ze strony człowiek ${ }^{98}$. Jako przykład może służyć historia Izraela, w której Żydzi doświadczali działania Boga. Jest to wzajemne prze-

\footnotetext{
93 IRA, s. 215.

94 PFHR, s. 295.

95 IRA, s. 226.

96 IRA, s. 228; A. Pintor-Ramos, Religación..., s. 330.

97 IRA, s. 222.

98 D. Gracia, Religación ... [s. 16 maszynopisu].
} 
nikanie się Boga i Żydów w historii tego narodu ${ }^{99}$, podczas którego Izraelici próbowali, czy Bóg jest prawdziwym Bogiem.

Druga forma to upodobnienie (conformación). Aby wypróbować szkic według tej formy doświadczenia, umieszcza się go we własnej rzeczywistości, aby doprowadzić do intymnej zażyłości z nim. Tutaj poznanie swojej głębi nie ma charakteru abstrakcyjnego, lecz ma charakter upodobnienia ${ }^{100}$. Jako przykład tego typu doświadczenia Zubiri podaje duchowość Mistrza Eckharta i św. Teresy z Ávila ${ }^{101}$. Warto dodać, że doświadczenie albo potwierdza wykreowany szkic, albo go nie potwierdza ${ }^{102}$.

Próbowanie szkicu przejawia się we wspomnianym zawierzeniu. Całkowite zawierzenie w stosunku do Boga wymaga bardzo konkretnej formy, którą jest właśnie religia ${ }^{103}$. W jej ramach ma miejsce całościowe zawierzenie człowieka próbowanemu obrazowi Boga ${ }^{104}$. Jak się ono dokonuje? Nawiązuje do religacji, gdy ludzka osoba jest wiedziona przez władzę rzeczywistości jako fundament w trzech wymiarach: ostateczności, stwarzania możliwości wyboru i przymuszenia do wybierania. Zaakceptowanie dawania się Boga polega na przyjęciu właśnie tych trzech wymiarów w tym sensie, że są one donacją Boga $^{105}$. W każdej religii dokonuje się to inaczej. Wyrazami zawierzenia są szacunek, prośba i szukanie schronienia człowieka w Bogu. Zdaniem Zubiriego, są to zasadniczo postawy metafizyczne, a nie religijne, gdyż są wyrazami wspomnianego wcześniej przyczynowania osobowego, to znaczy umacniają bycie (ser) osoby ludzkiej.

Jedną z postaci zawierzenia jest rozumiana metafizycznie wiara $(f e)$, czyli przylgnięcie (adhesión) ${ }^{106}$. Wiara angażuje się ze względu na prawdę realną, której pełnią ma być fundament. Wiara to zawierzenie innej rzeczywistości osobowej, o ile jest prawdziwa ${ }^{107}$; jest też jednocześnie próbą szkicu ${ }^{108}$. Zubiri pisze, że zgodnie z przyczynowaniem międzyosobowym powoduje pewną inkorporację w drugą osobę, czyli w Boga. To prowadzi do tego, że Bóg swoją prawdą osobową uzupełnia/wzmacnia (cobra) cechy prawdy osobowej tego, kto doń przylgnął. Przez to człowiek staje się bardziej prawdziwy: odkry-

99 IRA, s. 247-251

100 IRA, s. 257; J. Sáez Cruz, La accesibilidad..., s. 220-221; tenże: Sobre el problema de la realidad, Málaga 2013, s. 137-139, 323-326.

101 D. Gracia, Religación... [s. 15-16 maszynopis].

102 PFHR, s. 284.

103 PFHR, s. 83.

104 PFHR, s. 86.

105 HD, s. 492.

106 HD, s. 499-500; A. Pintor-Ramos, Dios..., s. 117.

107 HD, s. 229.

108 E. Solari, La raíz de lo sagrado, s. 347. 
ty, wierny i nieporuszony; innymi słowy, żyje pełniej ${ }^{109}$. Konkretne postacie omówionych postaw zawsze wyrażą się w jakiejś historycznej religii ${ }^{110}$.

Powyższe rozważanie Zubiri podsumowuje stwierdzeniem, że rozwinięcie religacji - jakim jest wiara - wywołuje zmianę wnętrza człowieka, którą nazywa nawróceniem - meta n oją. Filozof ten uznaje ponownie, że jest to temat stricte metafizyczny, gdyż wszystkie wspomniane akty religijne wywodzą się z przyczynowania osobowego. Bez niego, czyli bez realnego wpływu na metafizyczny wymiar życia osobowego istoty ludzkiej, akty religijne byłyby pozbawione wiary i zawierzenia ${ }^{111}$.

\section{Religia}

Każda historyczna religia to odniesienie do fundamentu boskości ${ }^{112}$. W religii człowiek zwraca się do Boga, aby podtrzymać swoje bycie (życie osobowe). Zubiri interpretuje historię religii nie z perspektywy teologicznej, ale teologalnej ${ }^{113}$, dlatego $\mathrm{w}$ tym ujęciu jest ona historią prób rozwiązania enigmy boskości (konfigurowania Ja) ${ }^{114}$. Kolejne próby niosą za sobą zawsze konkretną wizję Boga, człowieka i świata. Oczywiście zawsze dokonuje się to nie tylko w kontekście indywidualnym, ale szerszym, bo jest kulturowo uwarunkowane w ramach jakiegoś społeczeństwa ${ }^{115}$. W konsekwencji teologia, jako teoria dotycząca konkretnej relacji religijnej między bóstwem a człowiekiem i światem, jest zapodmiotowiona w wymiarze teologalnym człowieka. Jest to wymiar ludzki o tyle, o ile człowiek jest zakorzeniony we władzy rzeczywistości ${ }^{116}$. To, co teologalne, jest fundamentem tego, co teologiczne.

Problematyczność władzy boskości można wziąć w nawias. Mamy wtedy do czynienia jedynie z samym działaniem rzeczywistości jako rzeczywistości. Dlatego Zubiri mówi, że może być ona ujmowana jako boskość albo jako rzeczywistość jako taka (nuda realidad). Są to dwie różne perspektywy rzeczywistości i jej dwa różne wymiary. Gdy jest ujmowana jako taka, mamy do czynienia z tym, co nazywamy profanum, czyli świeckie. Natomiast ujęta z perspektywy boskości jest tym, co nazywamy religijnym, czyli odnoszącym

109 HD, s. 232-233.

110 HD, s. 499-500.

111 HD, s. 518.

112 PFHR, s. 62-63.

113 E. Rivera de Ventosa, Filosofía de la religión en X. Zubiri: Lo teologal y lo teológico, w: Exilios filosóficos de España, red. A.H. Soriano, Salamanca, s. 530-531.

114 PFHR, s. 60.

115 HD, s. 14.

116 HD, s. 16. 
się do religacji ${ }^{117}$. Dlatego, zdaniem Zubiriego, to, co świeckie jest przeciwstawione temu, co religijne, a nie święte ${ }^{118}$.

Religacja jest doświadczeniem ogólnoludzkim, natomiast religia jest już jej dobrowolnym rozwinięciem. W związku z tym można mówić o różnych jej momentach. Pierwszy to religacja do władzy rzeczywistości (wymiar teologalny - powszechny). Drugi to zaangażowanie intelektualne w stosunku do Boga szukanego w religacji (wynikający z woli prawdy) i doświadczenie (experiencia) napięciowe Boga, czyli sprawdzanie we własnym życiu poprzez zawierzenie i wiarę w ramach konkretnej religii (wymiar teologiczny). Są to trzy momenty jednego fenomenu, jakim jest religacja ${ }^{119}$. Dlatego Zubiri definiuje religię jako pewną formę - ucieleśnienie religacji (religión es plasmación de la religación). Religia to konkretna forma władzy rzeczywistości w religacji ${ }^{120}$.

W konsekwencji Zubiri rozumie historię religii nie jako pojawianie się i znikanie poszczególnych bóstw, tylko jako proces doświadczenia teologalnego $^{121}$. Historia religii to ukazanie wolnego i stopniowego rozwoju drogi, która człowiek przebył $\mathrm{w}$ stosunku do władzy boskości (el poder de la deidad) ${ }^{122}$. Człowiek w swoim duchu zaczyna interpretować impuls pochodzący z religacji $^{123}$. Historia ta pokazuje, że w każdym z bóstw jest obecna boskość. Historia religii na różne sposoby odwzorowuje jej postać ${ }^{124}$. Historia religii to historia relacji człowieka z Bogiem, a nie wartości religijnych (np. sacrum). To nie one są najważniejsze w religii, ale władza boskości ${ }^{125}$. Wartości religijne typu sacrum mogą pojawić się tam, gdzie uprzednio pojawi się postawa religijna, a nie odwrotnie ${ }^{126}$. Sacrum, to, co fascynujące, numinosum itp., jest wtórne wobec religacji. Sensy religijne są formą konkretną (plasmación), historyczną religacji w różnych religiach ${ }^{127}$.

Jako stałe elementy religii Zubiri wyróżnia to, co wypływa z jej genezy, czyli z doświadczenia władzy boskości. Pierwszy akt, służący wypracowaniu jakiejś religii pozytywnej, który człowiek zwróci ku jakiemuś bogu, będzie miał charakter oddawania czci (acatamiento de adoración), gdyż władza bo-

117 PFHR, s. 58-59.

118 PFHR, s. 26-28.

119 HD, s. 586; D. Gracia, Religación ... [s. 20 maszynopis].

${ }^{120}$ HD, s. 13.

121 D. Gracia, Religación ... [s. 20-21 maszynopis].

122 PFHR, s. 45.

123 A. Savignano, Zubiri y la filosofía de la religión, "Pensamiento", Vol. 71 extraordinario (2015), núm. 266, s. 433.

124 HD, s. 472.

125 PFHR, s. 26-28.

126 PFHR, s. 58-59.

127 A. Savignano, Zubiri y la filosofía de la religión, s. 430. 
skości jest ostateczna. Umożliwia ona (posibilitante), czyli daje człowiekowi możliwości do zrealizowania się, co w religii wyraża się poprzez przyznanie bóstwu bycia dawcą możliwości ludzkiego życia, rozwoju. Dlatego do bóstwa kieruje się prośby. Władza boskości ma także charakter nakłaniający, czego konsekwencją jest moralność religijna. Stąd jakikolwiek brak w stosunku do boskości otrzymuje status grzechu ${ }^{128}$.

\section{Prawda racjonalna (religijna)}

W wyniku doświadczenia (experiencia) można osiągnąć prawdę racjonalną dotyczącą fundamentu boskości. Ma ona miejsce wtedy, gdy zachodzi spotkanie (encuentro), to znaczy, gdy intelekcja rozumowa stwierdza, że rzeczywistość jest zbieżna lub nie jest zbieżna ze szkicem. Przeciwieństwem zbieżności jest błąd ${ }^{129}$. Im większa zbieżność, tym większa weryfikacja ${ }^{130}$. Spotkanie to spełnienie jakiegoś szkicu. Nie ma tu mowy o zwykłej zgodności (mera conformidad), tylko o intelekcji, w której to, co rzeczywiste, jest inteligowane jako spełniające (cumplimiento) szkic w procesie tworzenia $\mathrm{Ja}^{131}$. Dlatego prawda religijna to prawda doświadczana (verdad experiencial) ${ }^{132}$. Żadna weryfikacja nie jest absolutna. Jej niedościgłym kresem jest adekwatność ${ }^{133}$. W konsekwencji prawdy religijne to jedynie stadia marszu intelektywnego w kierunku prawdy rzeczywistości ${ }^{134}$. Trzeba pamiętać, że wedhug Zubiriego prawda to wydarzenie tymczasowe ${ }^{135}$. To także oznacza, że w odniesieniu do formuł dogmatycznych można mówić o stopniach zbieżności. Nikt nie ma przed oczami bóstwa. Zbieżność jest zatem w kierunku. Stąd prawda religijna to zbieżność drogi próbującej rozwikłać problem boskości z kierunkiem, który prowadzi do bóstwa ${ }^{136}$.

Bez wchodzenia w szczegóły ze względu na brak miejsca warto zauważyć, że według Zubiriego ateizm i agnostycyzm, tak jak zarysowany wyżej teizm, są także formami doświadczenia fundamentu. Nie można ich traktować jedynie jako czyste intelektualne ustosunkowanie się do fundamentu, lecz są postawą życiową, czyli doświadczeniem (experiencia). Wiemy, że każde

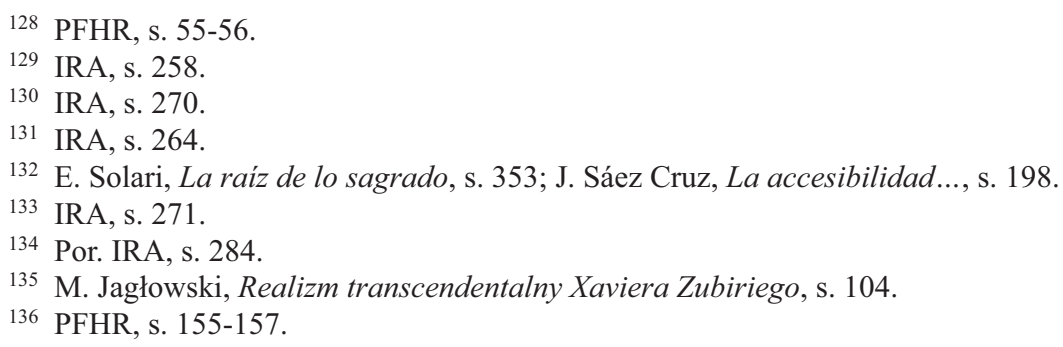


doświadczenie jest uwarunkowane indywidualnie, społecznie i historycznie. Dlatego stosunek do fundamentu jest tak różny ${ }^{137}$. Inaczej jest w przypadku indyferentyzmu czy też obojętności wobec władzy boskości, bo brak w nim woli fundowania. Człowiek zadowala się samym życiem. Ta postawa nie jest do utrzymania, czego powodem jest bezsporność religacji ${ }^{138}$.

\section{Kryterium prawdziwości religii}

W ramach fenomenologii religii wszystkie idee Boga są równe. Jedynie doświadczenie poszukujące rzeczywistości głębokiej jest w stanie tę równość zburzyć. Fenomenologia religii może jedynie stwierdzić, że nie ma jednej religii, która byłaby miarą prawdziwości pozostałych. W omawianym nurcie filozoficznym każda z nich jest prawdziwa we właściwy dla siebie sposób. Zasługą zaprezentowanej metafizyki religii Zubiriego jest próba wypracowania pewnego kryterium prawdziwości poszczególnych religii. Jest nim doświadczenie (experiencia), dzięki któremu możemy zweryfikować prawdziwość szkicu. Kryterium to próbuje wykazać, że jakaś droga religijna jest prawdziwsza niż inne (la más verdadera). W związku z tym pozostałe drogi religijne w mniej lub bardziej doskonały sposób przybliżają do Boga. Dzięki doświadczeniu istnieje możliwość znalezienia szkicu religijnego najbardziej zgodnego z faktami (religacja) i prawdziwego - lub mówiąc inaczej - najmniej nieadekwatnego w odniesieniu do faktów ${ }^{139}$.

Zubiri nie podaje jakiegoś wyraźnego kryterium zgodności szkicu z religacją. Ponieważ doświadczenie ludzkie ma charakter indywidualny, społeczny i historyczny, próby oceny prawdziwości jakiejś religii muszą zawierać te trzy wymiary ${ }^{140}$. Pierwszy $\mathrm{z}$ nich jest spełniony, gdy ludzkie życie $\mathrm{w}$ świetle szkicowanego i próbowanego fundamentu staje się bogatsze, prawdziwsze niż w innych przypadkach. Jeśli tak się dzieje, to dany szkic fundamentu należy rozumieć jako Boga ${ }^{141}$. Jednak kryterium to wydaje się trudne do zweryfikowania, bo każdy wierzący uznaje, że jego religia najbardziej go umacnia. Stąd Enzo Solari zauważa, że czasami Zubiri chce zawrzeć w wymiarze historycznym także wymiar indywidualny oraz społeczny, stwierdzając, że doświadczenie historyczne jest jedynym sędzią prawdy religijnej. Ludzka historia konstytuowana przez indywidua i społeczności jest tą, która pozwala zweryfikować to, co oferują poszczególne drogi religijne. To, co człowiek czyni z samym

137 HD, s. 12.

138 HD, s. 126-127.

139 E. Solari, La raíz de lo sagrado, s. 357-358.

140 Tamże, s. 360; F. Llenín Iglesias, La realidad divina, s. 159.

141 A. Pintor-Ramos, Religación ..., s. 331. 
sobą w czasie dzięki swoim możliwościom, jest tym, co obserwujemy w historii ludzkości. Historia jest procesem, w którym się weryfikuje prawdę głęboką szkiców religijnych. Stąd de facto tylko historia jest w stanie zweryfikować pozytywnie lub negatywnie, czy dana w ramach konkretnej religii rzeczywistość głęboka jest Bogiem ${ }^{142}$.

Ślad podobnego myślenia znajduje się w rozważaniach Gracii. Stwierdza on, że doświadczenie Boga zawsze wpływa na historię jako taką, po czym dodaje, że politeizm zanika na rzecz monoteizmu ${ }^{143}$. Można więc domniemywać, że sama historia eliminuje politeizm jako mniej prawdziwy (czyli mniej efektywny w historii).

Na koniec warto wspomnieć, aczkolwiek bardzo pobieżnie, że - zdaniem Zubiriego - to właśnie chrześcijaństwo jest tą najprawdziwszą religią, ponieważ najdoskonalej pasuje do religacji oraz najpełniej umacnia życie osobowe. Omawiany filozof dochodzi do wniosku, że religia ta ukazuje, iż rzeczy są „W” Bogu, to znaczy na kształt Boga (deiformes). Są Bogiem ad extra, bo Bóg stanowi ich fundament i przyczynę wewnętrzną ${ }^{144}$. Człowiek jest projekcją boskiego życia „na zewnątrz”, jest w skończony sposób obrazem życia Boga $^{145}$. Według Zubiriego taka też jest istota chrześcijaństwa. Jest ono przede wszystkim religią bycia formą Boga (deiformidad) ${ }^{146}$, a dopiero później religią zbawienia.

\section{XAVIER ZUBIRI'S POLEMICS WITH PHENOMENOLOGICAL CONCEPT OF RELIGION}

\section{Summary}

Zubiri does not accept the classical phenomenological concept of religion which unites religion with sacrum. He is constructing his own metaphysical concept of religion which he unites with the power that has reality. According to Zubiri, religion has its origin in power of the real which allows a person to have personal life. Zubiri's concept of religion allows to evaluate particular religions acknowledging that they may be more or less true. It is impossible for phenomenology of religion.

142 E. Solari, La raíz de lo sagrado, s. 360.

143 D. Gracia, Religación... [s. 23 maszynopis]; także: M.D. González, Dios, problema de todos, w: Voluntad de vida. Ensayos filosóficos, red. Seminario Zubiri - Ellacuría, Managua 1993, s. 86 .

${ }^{144}$ HD, s. 14-15. Por. D. Gracia, El tema de Dios en la filosofia de Zubiri, "Estudios Eclesiásticos" vol. 56, 216-217 (1981), s. 76-77.

145 X. Zubiri, El problema teologal del hombre: Cristianismo, Madrid 1999, s. 616.

146 HD, s. 15. 
Keywords: deity; the power of the real; the power of deity; the I; relegation; sketch; God/divinity

Słowa kluczowe: boskość; władza rzeczywistości; władza boskości; Ja; religacja; szkic; Bóg/bóstwo

\section{BIBLIOGRAFIA}

Eliade M., Sacrum, mit, historia, thum. A. Tatarkiewicz, Warszawa 1970.

González M.D., Dios, problema de todos, w: Voluntad de vida. Ensayos filosóficos, red. Seminario Zubiri - Ellacuría, Managua 1993, s. 77-91.

Gracia D., El tema de Dios en la filosofia de Zubiri, "Estudios Eclesiásticos” vol. 56, 216-217 (1981), s. 61-78.

Gracia D., Religación y religión en Zubiri, w: Filosofía de la religión, red. M. Fraijó, Trotta, Madrid 1994, s. 491-512 [dostępny tylko maszynopis].

Jagłowski M., Realizm transcendentalny Xaviera Zubiriego, Olsztyn 2000.

Llenín Iglesias F., La realidad divina. El problema de Dios en Xavier Zubiri, Oviedo 1990.

Otto R., Świętość. Elementy irracjonalne w pojęciu bóstwa i ich stosunek do elementów racjonalnych, tłum. B. Kupis, Warszawa 1999.

Pintor-Ramos A., Dios y el problema de la realidad en Zubiri, "Cuadernos de Pensamiento" 1 (1987), s. 107-121.

Pintor-Ramos A., Religación y "prueba” de Dios en Zubiri, "Razón y Fe" nov. 1988, s. 319-336.

Rivera de Ventosa E., Filosofía de la religión en X. Zubiri: Lo teologal y lo teológico, w: Exilios filosóficos de España, red. A.H. Soriano, Salamanca 1992, s. 515-531.

Savignano A., Zubiri y la filosofia de la religión, "Pensamiento", Vol. 71 extraordinario (2015), núm. 266, s. 425-434.

Sáez Cruz J., La accesibilidad de Dios: su mundanidad y transcendencia en X. Zubiri, Salamanca 1995.

Sáez Cruz J., Sobre el problema de la realidad, Málaga 2013.

Solari E., La raíz de lo sagrado. Contribuciones de Zubiri a la filosofia de la religión, Santiago de Chile 2010.

Zubiri X., El hombre y Dios, Madrid 2012.

Zubiri X., El problema filosófico de la historia de las religiones, Madrid 2006.

Zubiri X., El problema teologal del hombre: Cristianismo, Madrid 1999.

Zubiri X., Inteligencia sentiente. Inteligencia y realidad, Madrid 1984.

Zubiri X., Inteligencia y logos, Madrid 2008.

Zubiri X., Inteligencia y razón, Madrid 2008.

RAFAŁ S. NIzıŃSKI - adiunkt w Zakładzie Filozofii Chrześcijańskiej UAM. Zajmuje się filozofią Boga, a w związku z tym także metafizyką i epistemologią. Uwagę badawczą koncentrował na: metafizyce M. Heideggera, filozofii Boga Ch. Hartshorne'a, teologii K. Bartha - problemie racjonalności wiary, filozofii Boga X. Zubiriego (obecna dziedzina badań), mistyce karmelitańskiej św. Jana od Krzyża oraz św. Teresy od Jezusa, a także na filozofii mistyki. Opublikował kilka pozycji książkowych, artykułów oraz prac pod swoją redakcją. 